\title{
Strengthening Ihsan Behavior (Always do the Good Deeds)
}

By A. Ilyas Ismail \& Iffah Budiningsih

Syarif Hidayatullah State Islamic University

Abstract- The purpose of this study was to determine the best model in predicting insan behavior, especially during the Covid 19 pandemic as it is currently from eight insan character: ambitious, certain/confident, courageous, hard-working, enthusiastic, patient and persistent, generous, and grateful. The method of research was survey and 215 students at As Syafi'iyah Islamic University were selected as the sample. The results revealed that: a) only three out of eight qualities that significantly influenced the development of insan behavior, namely ambitious, patient \& persistent, and generous; b) the qualities of ambitious, patient \& persistent, and generous simultaneously contributed to shaping insan behavior by $58.5 \%$; c) the best mathematical model to predict insan behavior was $Y=-0.465+0.211 X 1+0.413 X 2+0.453 X 3$ (X1=ambitious; $X 2=$ patient \& persistent; $X 3=$ generous); d) being generous served as the quality with the highest sensitivity of the effect on insan behavior (always do the good deeds) development, followed by patient \& persistent and ambitious.

Keywords: ihsan behavior, generous, patient \& persistent, ambitious.

GJHSS-G Classification: FOR Code: 330199

Strictly as per the compliance and regulations of:

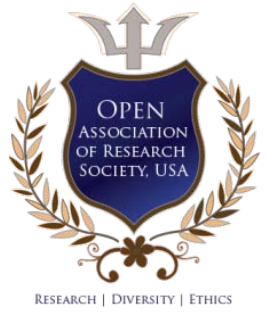

(c) 2021. A. Ilyas Ismail \& Iffah Budiningsih. This is a research/review paper, distributed under the terms of the Creative Commons Attribution-Noncommercial 3.0 Unported License http://creativecommons.org/licenses/by-nc/3.0/), permitting all non-commercial use, distribution, and reproduction in any medium, provided the original work is properly cited. 


\title{
Strengthening Ihsan Behavior (Always do the Good Deeds)
}

\author{
A. Ilyas Ismail ${ }^{\alpha} \&$ Iffah Budiningsih ${ }^{\sigma}$
}

\begin{abstract}
The purpose of this study was to determine the best model in predicting ihsan behavior, especially during the Covid 19 pandemic as it is currently from eight ihsan character: ambitious, certain/confident, courageous, hard-working, enthusiastic, patient and persistent, generous, and grateful. The method of research was survey and 215 students at As Syafi'iyah Islamic University were selected as the sample. The results revealed that: a) only three out of eight qualities that significantly influenced the development of ihsan behavior, namely ambitious, patient \& persistent, and generous; b) the qualities of ambitious, patient \& persistent, and generous simultaneously contributed to shaping ihsan behavior by $58.5 \%$; c) the best mathematical model to predict ihsan behavior was $Y=-0.465+0.211 X_{1}+0.413 X_{2}+0.453 X_{3}$ $\left(X_{1}=\right.$ ambitious; $X_{2}=$ patient \& persistent; $X_{3}=$ generous); d) being generous served as the quality with the highest sensitivity of the effect on ihsan behavior (always do the good deeds) development, followed by patient \& persistent and ambitious.
\end{abstract}

Keywords: ihsan behavior, generous, patient \& persistent, ambitious.

\section{INTRODUCTION}

ducation functions to enhance both technical skills and positive qualities, including moral and positive values. These two aspects are crucial for people to equitably possess in order that they can get through this global era, improve life quality, and avoid destruction. Lack of religious, moral, and positive values will lead to a destructive application of science and technology, such as war and abuse, which can also be impactful on changing the essence of humans and humanity, viz; genetic revolution (cloning). Humans tend to misuse science and technology; thus, moral and religious values are considered of great importance. Such values can guide and control the use of science and technology for human's virtue without demeaning or changing the nature of humanity.

Moral and religious values education in children is mostly implemented by their family and the surrounding environment. One's values will be a reference to shaping their characters that also influence their act or behavior. Characters are positive values inherent in humans from the process of long-term

Author $\alpha$ : Faculty of Da'wa and Communication, Syarif Hidayatullah State Islamic University, Jl. Ir.H. Juanda, Cempaka Putih, Kota Tangerang, Indonesia.e-mail: a.ilyas@uinjkt.ac.id

Author o: Faculty of Teaching and Educational Sciences, As-Syafi'iyah Islamic University, Jl. Raya Jatiwaringin No 12, Pondok Gede, Jakarta Timur, Indonesia.e-mail: iffahbudiningsih@gmail.com habituation. They are embodied in thoughts, attitudes, feelings, words, and acts. Parents, schools, and all educational institutions should be held accountable for character education. As mentioned earlier, positive characters or qualities undergo a long process, in terms of continuous habituation, on a daily basis. Ismail (2018: 111) claims that Ihsan is one of the essential teachings in Islam, yet it is not primarily understood. Ihsan means 'excellence' and 'try to be better', so that ihsan behavior refers to doing good deeds and becoming better. In the Qur'an Surah Al-Qasas [28:77], we are instructed to do good as Allah has done good to us. By making Allah the center of orientation, we will reach success and avoid a sinful act. Surah Al-Qasas [28:77] means:

"And seek with the (wealth) which Allah has bestowed to you the Hereafter, and do not forget your share (enjoyment) of this world, and do good (to others) as Allah has done good to you, and do not make mischief in the land. Indeed, Allah does not like those who do mischief".

In addition, according to Ismail (2018:113-114), the command of doing ihsan does not only revolve around worship, but also working and doing business. It generally has a particular meaning of a) doing something properly with utmost responsibility; b) achieving better than others, implying that we need to be one who is foremost in good deeds not who wrongs one-self.

Many qualities affect the behavior of ihsan. An in-depth interview with 17 university students (eighth semester) in the academic year of 2019/2020 reveals that there are three out of eight qualities that dominantly influence ihsan behavior (based on respondents' perceptions). Below is the detail. 
Table 1: Recapitulations of In-depth Interview Results regarding 3 Dominant Qualities Presumed to Influence IHSAN Behavior

\begin{tabular}{ccccccccc}
\hline Positive & \multicolumn{2}{c}{$\begin{array}{c}\text { Selecting First } \\
\text { Sequence }\end{array}$} & $\begin{array}{c}\text { Selecting Second } \\
\text { Sequence }\end{array}$ & $\begin{array}{c}\text { Selecting Third } \\
\text { Sequence }\end{array}$ & \multicolumn{2}{c}{ Total } \\
\cline { 2 - 10 } & $\begin{array}{c}\text { Number of } \\
\text { Respondents }\end{array}$ & $\%$ & $\begin{array}{c}\text { Number of } \\
\text { Respondents }\end{array}$ & $\%$ & $\begin{array}{c}\text { Number of } \\
\text { Respondents }\end{array}$ & $\%$ & $\begin{array}{c}\text { Number of } \\
\text { Respondents }\end{array}$ & $\%$ \\
\hline Grateful & 8 & 47.0 & 6 & 35.3 & - & - & 14 & 82.3 \\
\hline Certain/Confident & 4 & 23.6 & 3 & 17.6 & 4 & 23.6 & 11 & 64.8 \\
\hline $\begin{array}{c}\text { Patient and } \\
\text { Persistent }\end{array}$ & - & - & 5 & 29.4 & 2 & 11.8 & 7 & 41.2 \\
\hline
\end{tabular}

It is expected that this study can discover a mathematical model to improve Ihsan behavior, i.e., what qualities that dominantly affect such behavior. Following the results of the in-depth interview with 17 respondents, the respondents are presumed to have the qualities of being grateful, certain/confident, patient \& persistent that strongly influence insan behavior. The purpose of this study is to find a mathematical model that can grow and strengthen positive qualities 'ihsan behavior' in living the life. This model can be utilized by educators/teachers, parents, and other people in shaping and strengthening positive characters to the successor to today's generation of Indonesia that dominantly affect ihsan behavior. On that ground, this study is conducted to paying attention to eight positive qualities that mostly influence one's ihsan behavior, especially during the Covid 19 pandemic as it is currently, and namely ambitious, certain/confident, courageous, hard-working, enthusiastic, patient and persistent, generous, and grateful. Additionally, the problem formulated in this study is whether or not there is a positive and simultaneous correlation between eight qualities mentioned above and ihsan behavior; the dominant qualities that influence insan behavior; and the best mathematical model (Good of Fit Model/Gof Model) to predict such behavior. Below is the detail of the concepts of ihsan behavior, along with eight positive qualities that are presumed to affect ihsan behavior.

\section{a) Ihsan Behavior}

In the realm of Islam, the attempt to always do the good deeds (do not make mischief) as Allah has been good to us is known as Ihsan. It is also stated in the Qur'an Surah Al-Qasas [28:77] that means: "And seek, with the (wealth) which Allah has bestowed to you, the Hereafter, and do not forget your share (enjoyment) of this world, and do good (to others) as Allah has done good to you, and do not make mischief in the land. Indeed, Allah does not like those who do mischief". (QS. Al-Qasas/28:77). Ihwanto et al. (2017: 9) point out that the values of insan behavior are in three scopes of qualities, including ihsan knowledge, ihsan feeling, and ihsan action. Ihsan knowledge, in particular, refers to the cognitive dimension developed by Bloom in Anderson \& Kratwohl (2001: 28), i.e., remembering, understanding, applying, analyzing, evaluating, and creating. Ismail (2018:113-127) also explains that ihsan behavior associates with working professionally, and in Islam perspectives, is impacted by five factors, as follows: a) intention (work commitment and motivation; b) knowledge/competence; c) capability; d) time management, and; e) technological support. Next, Bakar (1994:11) opines that Islam does not only teach what we have to do (skill), but also what we need to know (competence). Accordingly, ihsan behavior requires competence and skill to work. Time management is also necessary to support work quality (ihsan behavior) for Islam views time management as worship, and ignoring time means a big loss that cannot be recovered as written in the QS. Al-'Asr (103):1-3. In this period of intense competition, technological support is vital to help the process of having done work quickly and accurately. Therefore, technology literacy is highly required in all aspects of life in order to finish the work effectively (ihsan behavior). The United Nations in the book entitled United Nations Competency DevelopmentA Practical Guide (2010:109) mention positive indicators of technological awareness, which are a) keeping up with technology; b) comprehending the application and limitation of technology to work; c) making an effort to apply technology for appropriate tasks; d) showing willingness to learn new technology. Furthermore, Wahab \& Ismail (2019:198) explained that in general the characteristics of Insan's behavior include: sincere \& efficient work, generous, high responsibility, love to help, very careful in working, able to go the extra mile to achieve optimal performance. Ultimately, ihsan behavior refers to performing good deeds regularly and striving to better what has been done. This behavior is characterized by a) taking on responsibilities for the work (commitment); b) work motivation; c) improving competencies (knowledge, skill, and attitude); d) possessing time management skills; e) having the ability to use technology.

\section{b) Ambition}

Ambition is a strong desire as the starting point to achieve or create something big. As argued by Yulk (2013:100), ambition refers to a picture of the desired future, not a complicated plan with quantitative objectives and detailed actions. It is future goals to reach based upon today's reality. A weak desire will not 
certainly produce significant results or improvement. Ismail (2018: 44-45) notes that being ambitious has three functions, viz; a) as a blueprint to ease the process of achieving the desire; b) as a direction to arrive at the desire; c) as a trigger to act. Moreover, Hill (2013: 23-24) states that a vision is not a dream nor wishful thinking, yet it should be followed by a) goals, in which the ambition or desire is vividly and specifically depicted, so that it will be measurable, observable, and achievable in a certain period; b) strong desires, in terms of setting up one's sights on actualizing the desires with sacrifice, time, and realistic plans; c) persistence to achieve the desires and to address every challenge one confronts. All in all, ambition is defined as a strong desire as the starting point to result in a great thing with the following indications: a) measurable goals; b) strong willingness to realize the desires; c) persistence to reach the desires; d) continuous follow-up plans.

\section{c) Certainty/Confidence}

From the epistemological review, the word certainty comes from Arabic al Yaqin that literally means science/knowledge so that the truth is achieved. In the perspective of Islam, certainty is viewed as belief or conviction, referring to a mental condition when a person realizes that his/her opinions and actions are right. Besides, certainty is also considered mental assurance that something is right or valid. As a mental attitude that is based on what is considered true, certainty has become a powerful feeling, making it hard to alter and be altered. An individual with substantial certainty usually had firm and consistent life principles or norms. However, certainty is dissimilar to preference; preference is negotiable, whereas certainty is the other way around. According to llyas (2018: 50), in Islamic epistemology, 'truth' has some degrees, as follows: a) refers to knowledge (assumption); b) measurable vision; c) the level of truth gained through experience (not only by sight) so that one will find out that his/her act is 'true' through self-talk. Alias (2017:15) mentions two degrees of knowledge certainty, which are positive certainty and negative certainty. The negative knowledge certainty can be deprived by the values of making it turn to positive knowledge certainty. In conclusion, being certain or confident is a mental condition and affective state that is appreciative of the truth. It is affected by several factors, including a) striving for the truth; b) strong life principles and norms; c) knowledge mastery; d) positive thinking; e) self-talk.

\section{d) Courage}

In Arabic, courage is widely known that refers to a mental attitude leading someone to have a willingness to keep moving forward, be persistent and fearless. Muslims are obliged to strive for goodness (ihsan behavior), as narrated by Abu Hurairah in Shahih Muslim: "Strong believers are better and more beloved to Allah than weak believers". From the perspective of
Islam, courage is viewed as the base of noble morals. Imam Ghazali in llyas (2018: 55) regards courage as one of the five items for devout Muslims. The other four include a) knowledge and wisdom; b) generosity; c) justice; d) honesty. Moreover, llyas expresses that a courageous person is characterized by a willingness to sacrifice for goals and desires, as well as to take risks. King (2010: 37) claims that courage is influenced by a) visions or goals to be achieved; b) actions or efforts in reaching goals; c) passion or situation to bear up in achieving goals. If these matters are met, a person can deal with anxiety, doubt, and fear. To sum up, courage is a mental attitude that makes an individual willing to move forward, be persistent, and fearless to fulfill the desire or to maintain glory and honor. Being courageous is indicated by a) willingness to sacrifice for success; b) being generous; c) willingness to take risks.

\section{e) Hard Work}

In the realm of Islam, hard work is viewed in many dimensions, i.e., physical, intellectual, and spiritual. Hard work, as defined by Hariyoto in Handayani \& Sumaryati (2014: 31), is a persistent effort, with no despair, to succeed. Ilyas (2018: 67-75) argues that hard work comprises three meanings, including:

a. Physical hard work or effort: working to produce something tirelessly, staying oneself away from indolence and temptation, along with being disciplined.

b. Intellectual hard work or effort: innovative thinking in the form of being creative, critical, and breaking out of comfort zone in order that new opportunities and value-added are created.

c. Spiritual hard work or effort: an ability/effort to live a meaningful life, i.e., how one can do good to others more excessively.

d. Moral hard work or effort: an ability to take a good act (according to prevailing religious norms in society) consistently; if applied in a long-term manner, moral hard work will be a character.

Ardi in Handayani \& Sumaryati (2014:31) describes the characteristics of hard-working people, namely being determined, tenacious, careful, disciplined, patient, sincere, persistent, valuing time, and working smartly. In short, hard work is one's ability and strength that involve physical, intellectual, moral, and spiritual efforts to arrive at the goals, as indicated by a) producing something tirelessly/keeping oneself away from indolence; b) being highly disciplined; c) being innovative, creative, critical, and breaking out of comfort zone; d) doing good/being helpful more excessively to others; e) obeying prevailing religious norms and ethics.

\section{f) Ghirah/Enthusiasm}

In this study, Ghirah means an awareness of always moving forward to succeed; if necessary, a person should be very successful beyond limits at 
whatever s/he does. The Prophet Muhammad encourages us to be jealous of the high-flyers. There is enthusiasm in ghirah that has some literal meanings, such as:
a. A feeling of excitement (inspiration as if by a divine or superhuman power);
b. Great eagerness in human's soul that comes from the [strength of] God;
c. Determination that refers to a positive emotion and persevering efforts towards difficult goals despite obstacles. It is not only a cognitive state, but also an affective state and action towards the goals. Determination also comprises persistence when people keep going until they get what they have been ambitious for. Determination and persistence will make them win, "Nobody fails at anything until they reach the stage when they finally give up."

A study conducted by Alwi et al. (2016: 43) reveals that an employee that has a great enthusiasm will always do their best to enhance their skills in carrying out their duties for organizational effectiveness. This implies that an individual with an intense eagerness in organizational work is most likely to do good deeds (ihsan behavior), i.e., creating a more effective organization. On top of that, Subiantoro et al. (2019: 425) states that an enthusiastic employee is characterized by working with pleasure, accomplishing tasks punctually, having a dynamic interaction and optimum participation, collaborating with coworkers, and being innovative. Considering the above description, it is concluded that ghirah is a strong consciousness in working to achieve goals, and it is the energy to keep struggling (jihad). Ghirah is indicated by a) happiness; b) great enthusiasm; c) determination; d) persistence; e) sedulity.

\section{g) Patience \& Persistence (Willpower)}

Being patient is one of the human qualities that its virtues have been mentioned a hundred times in 90 places in the Qur'an. Patience refers to a) an ability to control oneself from badness; b) an ability to restrain from adversity/misery. Being hopeless (low willpower) may be instilled since childhood, when parents unwittingly taught their children to be hopeless. For instance, a father did not let his children to gain new experiences or to learn how to deal with obstacles. Ernadewita \& Rosdialena (2019: 62-63) define patience as an ability to restrain oneself from horrible things for Allah's blessing. However, being patient is not only applied to such things, viz; disaster, decease, illness, hunger, and the like, but also to worldly desires. For this reason, patience is a process of self-mastery from both worldly desires and unpleasant situations. Research results found by Dweck in Stoltz (1997:70) prove that individuals' responses to difficulties are influenced by parents, teachers, peers, and people who play an important role during their childhood. Those who address a problem with toughness, self-control, and commitment will remain tenacious in confronting one (Oullette in Stoltz, 1997: 70). Moreover, Subandi (2011: 225) finds out five categories included in the concept of patience, namely a) self-restraint: holding back emotions and desires, thinking long, forgiving, tolerating procrastination; b) fortitude in the face of adversity; c) persistence: working hard and tenaciously to reach goals and solve problems; d) sincerity and gratitude in coping with harsh life truths; e) taking time (no rush). All in all, willpower (being patient and persistent) is defined as one's tendency to positively respond to and bear up adversity that obstructs goal achievement. Patience and persistence are measured by a) tendency to control adversity; b) acknowledging adversity and its consequences; c) tendency to limit adversity; d) the length of facing adversity.

\section{h) Generosity}

A believer is enjoined to continue the love of Allah SWT and the Prophet by being generous with other human beings, as mentioned in QS. At-Tawbah [9:128] which means: "There has certainly come to you a Messenger from among yourselves. Grievous to him is what you suffer; [he is] concerned over you and to the kind and merciful believers" (QS. At-Tawbah/9:128). By referring to the previous verse, the traits of the Prophet Muhammad regarding generosity and philanthropy that should be exemplified encompass a) sense of crisis: an ability to sense others' crisis; b) sense of achievement: having a strong desire to get other people/nation successful; c) sense of love to all human beings. Growing generosity and philanthropy includes the following three qualities:

a. Empathy: the ability to understand other people's adversity;

b. Sympathy: moral and material support to lighten problems and suffering; empathy is usually followed by sympathy.

c. Philanthropy: a condition of 'giving not getting'. Allah SWT is The Bestower; giving is the characteristics of nature; for instance, sun, ocean, rivers, and plants give benefits to humans without expecting something in return.

Those three qualities (empathy, sympathy, and philanthropy) should be developed to become one's inherent characters. Tabi'in (2017:39) expresses that being generous (social care) is an attitude and act of being helpful to other people in needs. Hence, it requires the ability to turn attention to the surrounding environment. According to Utami et al. (2019:21), the characteristics of generosity are a) showing empathy; b) willing to establish a relationship with other individuals; c) doing unfortunate people a big favor. Additionally, Alma et al. (2010: 206) bring up some matters that can decrease the generosity of a person, including a) letting people suffer without giving a hand; 
b) being apathetic over the environment; c) getting uninvolved in community's activities.

In conclusion, generosity refers to the ability to understand and concern about others' feelings or problems and give them some help. Being generous is also characterized by a) empathy: sensing other people's adversity; b) sympathy: providing moral support; c) philanthropy: performing charitable acts, in terms of material support.

i) Gratitude

Gratitude, in Arabic, is rooted from 'syakarat alsyajarah' which means 'growing'. Besides, Ismail (2018:142) argues that it contains three meanings, as follows:

a. Realizing that the grace comes from Allah SWT, and it is called Grateful with the Heart.

b. Utilizing the grace and gift from Allah SWT the way they are intended for, and it is named Grateful with Words and Acts.

c. Renewing the grace and gift from Allah SWT by growing and developing them. In this case, being grateful is the highest levels Allah SWT has instructed to The Prophet Muhammad in the first revelation of the early days of prophecy.

According to Imam Ghazali, gratitude encompasses the following awareness:

a. Awareness that Allah SWT gives all grace and gifts; unconsciousness will lead to ingratitude.

b. Awareness that all grace and gifts one has are greater than needed, as such, getting him/her thankful to Allah SWT.

c. Awareness that being grateful will make someone grow better.

Akmal \& Masyuri (2018:20) propose the essence of gratitude, such as a) accepting the grace and gifts from Allah SWT with pleasure; b) being grateful for everything Allah has given by saying Alhamdulillah
(Praise be to God); c) carrying out His commands and sharing things with other people. Furthermore, Haryanto \& Kertamuda (2016:113) also give five categories of gratitude, namely accepting, thanking, enjoying, appreciating, and utilizing. Accordingly, this study defines being grateful as one's behavior that is based on a) awareness and belief that grace, gift, and disaster are from Allah SWT; b) awareness and belief that the grace and gift one possesses are huge; c) positive thinking; d) self-improvement (high productivity).

\section{il. Research Method}

The purpose of this study was twofold; it was to obtain data empirically regarding a) the correlation between eight positive qualities (ambitious, certain/ confident, hard-working, ghirah/enthusiastic, patient and persistent, generous, and grateful) and ihsan behavior, and; b) to find out the best model (Good of Fit Mode/) to predict insan behavior. This present work relied on a quantitative survey and involved 4,000 students at As Syafi'iyah Islamic University as the population; and only 215 of them were selected as the sample by random sampling. Data analysis used the multiple regression analysis with SPSS program between variable $X_{1}-X_{8}$ towards variable $Y$. The data were collected from a nontest instrument (questionnaire) and Likert scale; the scale ranges from 1 to 5 with the following description: 5 = strongly agree, $4=$ agree, $3=$ neither agree nor disagree, 2 = disagree, and $1=$ strongly disagree.

\section{a) Research Variables and Indicators}

The dependent variable of this research was insan behavior ( $Y$ ), and the independent variables comprised ambitious $\left(X_{1}\right)$, certain/confident $\left(X_{2}\right)$, courageous $\left(X_{3}\right)$; hard-working $\left(X_{4}\right)$; ghirah/enthusiastic $\left(X_{5}\right)$; patient \& persistent $\left(X_{6}\right)$; generous $\left(X_{7}\right)$; and grateful $\left(X_{8}\right)$. Each variable indicator was presented in the following table.

Table 2: Instrument Summary of Variable $\mathbf{Y}, \mathbf{X}_{1}, \mathbf{X}_{2}, \mathbf{X}_{4}, \mathbf{X}_{5}, \mathbf{X}_{6}, \mathbf{X}_{7}, \mathbf{X}_{8}$

\begin{tabular}{|c|c|}
\hline VARIABLES & INDICATORS \\
\hline Ihsan Behavior (Y) & $\begin{array}{ll}\text { - } & \text { Having work responsibilities; } \\
\text { - } & \text { Having work motivation; } \\
\text { - } & \text { Improving competencies (knowledge, skill, attitude); } \\
\text { - } & \text { Possessing time management skills; } \\
\text { - } & \text { Being able to use information and communication technology; }\end{array}$ \\
\hline Ambitious $\left(X_{1}\right)$ & $\begin{array}{l}\text { - Having measurable goals; } \\
\text { - } \quad \text { Possessing strong desires to achieve the goals; } \\
\text { - } \quad \text { Being persistent to achieve the goals; } \\
\text { - Having continuous follow-up plans. }\end{array}$ \\
\hline Certain/Confident $\left(\mathrm{X}_{2}\right)$ & $\begin{array}{ll}\text { - } & \text { Striving for the truth; } \\
\text { - } & \text { Possessing firm life principles and norms; }\end{array}$ \\
\hline
\end{tabular}




\begin{tabular}{|c|c|}
\hline & $\begin{array}{l}\text { - } \text { Mastering knowledge; } \\
\text { - } \quad \text { Thinking positively; } \\
\text { - } \quad \text { Having self-talk } \\
\end{array}$ \\
\hline Courageous $\left(X_{3}\right)$ & $\begin{array}{ll}\text { - } & \text { Willing to sacrifice for success; } \\
\text { - } & \text { Being generous; } \\
\text { - } & \text { Willing to take risks; } \\
\end{array}$ \\
\hline Hard-working $\left(\mathrm{X}_{4}\right)$ & $\begin{array}{l}\text { - } \quad \text { Producing something tirelessly; } \\
\text { - } \quad \text { Being highly disciplined; } \\
\text { - } \quad \text { Being innovative, creative, critical, and breaking out of comfort zone; } \\
\text { - } \quad \text { Doing good/being helpful more excessively; } \\
\text { - } \quad \text { Obeying prevailing religious norms and ethics } \\
\end{array}$ \\
\hline Ghirah $\left(X_{5}\right)$ & $\begin{array}{l}\text { - } \text { Happiness; } \\
\text { - } \quad \text { Great enthusiasm; } \\
\text { - } \quad \text { Determination; } \\
\text { - } \\
\text { - } \\
\text { Persistence; } \\
\end{array}$ \\
\hline $\begin{array}{c}\text { Patient \& Persistent } \\
\left(\mathrm{X}_{6}\right)\end{array}$ & $\begin{array}{l}\text { - } \quad \text { Tending to control adversity; } \\
\text { - } \quad \text { Acknowledging adversity and its consequences; } \\
\text { - } \quad \text { Tending to limit adversity; } \\
\text { - } \quad \text { The length of facing adversity. }\end{array}$ \\
\hline Generous $\left(X_{7}\right)$ & $\begin{array}{ll}\text { - } & \text { Having empathy (sensing other people's adversity); } \\
\text { - } & \text { Having sympathy (providing moral support); } \\
\text { - } & \text { Philanthropy (performing charitable acts, in terms of material support). }\end{array}$ \\
\hline Grateful $\left(\mathrm{X}_{8}\right)$ & $\begin{array}{l}\text { - Having awareness and belief that grace, gift, and disaster are from Allah SWT; } \\
\text { - Having awareness and belief that the grace and gift one possesses are greater than } \\
\text { - } \quad \text { needed; } \\
\text { - } \quad \text { Selfinking positively; } \\
\text { rimprovement (having high productivity). }\end{array}$ \\
\hline
\end{tabular}

b) Instrument Validity and Reliability Tests

Testing the instrument was conducted prior to using it during the data collection process. This was to examine its validity by applying the formula of $r$ Pearson
Product Moment. The formula of $r$ Cronbach Alpha was also used to test the instrument reliability. Provided below are the results of instrument validity and reliability tests.

Table 3: The Results of Validity and Reliability Tests of Variable $Y$ and $X_{1}-X_{8}$

\begin{tabular}{ccccc}
\hline Variables & $\begin{array}{c}\text { Valid } \\
\text { Question } \\
\text { Items }\end{array}$ & Value of r Count (Pearson) & Reliability Coefficient & Desc. \\
\hline Ihsan Behavior $(Y)$ & 15 & $0.370-0.693$ & 0.829 & Valid \& Reliable \\
Ambitious $\left(X_{1}\right)$ & 11 & $0,375-0.773$ & 0.823 & Valid \& Reliable \\
Certain/Confident $\left(X_{2}\right)$ & 11 & $0.311-0.627$ & 0,660 & Valid \& Reliable \\
Courageous $\left(X_{3}\right)$ & 13 & $0.343-0.677$ & 0.808 & Valid \& Reliable \\
Hard-working $\left(X_{4}\right)$ & 15 & $0.353-0.587$ & 0.528 & Valid \& Reliable \\
Ghirah $\left(X_{5}\right)$ & 13 & $0.329-0730$ & 0.764 & Valid \& Reliable \\
Patient \& Persistent $\left(X_{6}\right)$ & 14 & $0.309-0.602$ & 0.706 & Valid \& Reliable \\
Generous $\left(X_{7}\right)$ & 13 & $0.309-0.602$ & 0.672 & Valid \& Reliable \\
Grateful $\left(X_{8}\right)$ & 10 & $0.347-0.540$ & 0.672 & Valid \& Reliable \\
\hline & & & &
\end{tabular}




\section{Result}

Requirement analysis testing was conducted before multiple regression analysis.

Normality Test: observation data are normally distributed (around the diagonal line), so that the regression model is feasible to use.

a. Heteroscedasticity Test: Heteroscedasticity does not occur; thus, the regression model is worth using.

b. Multicollinearity: The tolerance value arrives at 1 , or VIF (Variance Inflation Factor) is less than 10, so that no multicollinearity; Table 6 displays the tolerance value of around 1 and $\mathrm{VIF}<10$, meaning that the regression model is feasible to employ.

c. Autocorrelation Test: The value of $\mathrm{D}-\mathrm{W}$ is 1.884 , implying that there is no autocorrelation because the D-W value is between -2 to 2; simply put, the regression model is worth applying.

All four analysis requirements mentioned above have been fulfilled, in which variable $Y, X_{1}, X_{2}, X_{3}, X_{4}, X_{5}$, $X_{6}, X_{7}, X_{8}$ are normally distributed. Variable $Y$ on $X_{1}, X_{2} X_{3}$, $X_{4}, X_{5}, X_{6}, X_{7}$, and $X_{8}$ has no heteroscedasticity; the tolerance value of $X_{1}, X_{2}, X_{3}, X_{4}, X_{5}, X_{6}, X_{7}$, and $X_{8}$ is around 1 or the value of VIF $<10$; the $\mathrm{D}-\mathrm{W}$ value is between -2 to 2 .

a) Results of Correlation and Multiple Regression Analysis

The analysis result of the simultaneous correlation between ambitious $\left(X_{1}\right)$, certain/confident $\left(X_{2}\right)$, courageous $\left(X_{3}\right)$, hard-working $\left(X_{4}\right)$, ghirah $\left(X_{5}\right)$, patient \& persistent $\left(X_{6}\right)$, generous $\left(X_{7}\right)$, and grateful $\left(X_{8}\right)$ and ihsan behaviour $(Y)$ generates multiple correlation coefficient of $R=0.77$. Hence, such a correlation is 'positive and strong'. Meanwhile, the determination coefficient $\left(R^{2}\right)$ gets a value of 0.593 (rounded to 0.60 ) and is significant. Due to the fact that the sig value $<0.05(0.00<0.05)$, variables of ambitious $\left(X_{1}\right)$, certain/confident $\left(X_{2}\right)$, courageous $\left(X_{3}\right)$, hard-working $\left(X_{4}\right)$, ghirah $\left(X_{5}\right)$, patient \& persistent $\left(X_{6}\right)$, generous $\left(X_{7}\right)$, and grateful $\left(X_{8}\right)$ simultaneously contribute to shaping insan behavior ( $Y$ ) by $60.0 \%$; the remaining $40.0 \%$ is contributed by other factors. The overall analysis results of the multiple correlation coefficient and the determination coefficient are given in the table below.

Table 4: Multiple Correlation of $Y \& X_{1-8}$

\begin{tabular}{|c|c|c|c|c|c|c|c|c|c|}
\hline \multicolumn{10}{|c|}{ Model Summary ${ }^{b}$} \\
\hline Model & $\mathrm{R}$ & $\begin{array}{c}\mathrm{R} \\
\text { Square }\end{array}$ & $\begin{array}{l}\text { Adjusted R } \\
\text { Square }\end{array}$ & $\begin{array}{l}\text { Std. Error of the } \\
\text { Estimate }\end{array}$ & $\begin{array}{c}\text { R Square } \\
\text { Change }\end{array}$ & $\begin{array}{c}\text { Change St } \\
\text { F } \\
\text { Change }\end{array}$ & $\begin{array}{l}\text { latistics } \\
\text { df1 df2 }\end{array}$ & $\begin{array}{l}\text { Sig. F } \\
\text { Change }\end{array}$ & $\begin{array}{l}\text { Durbin- } \\
\text { Watson }\end{array}$ \\
\hline 1 & $.770^{a}$ & .593 & .571 & .28453 & .593 & 26.582 & 8146 & .000 & 1.844 \\
\hline
\end{tabular}

a. Predictors: (Constant), ambitious, certain/confident, courageous, hard-working, ghirah, patient \& persistent, generous, and grateful.

b. Dependent Variable: Ihsan Behavior

The result of ANOVA regarding the $\left(X_{4}\right)$, ghirah $\left(X_{5}\right)$, patient \& persistent $\left(X_{6}\right)$, generous $\left(X_{7}\right)$, simultaneous correlation between ambitious $\left(X_{1}\right)$, and grateful $\left(X_{8}\right)$ and ihsan behavior $(Y)$ can be seen in certain/confident $\left(X_{2}\right)$, courageous $\left(X_{3}\right)$, hard-working the following Table 5 and Table 6 :

Table 5: ANOVA of $\mathrm{Y}$ on $\mathrm{X} 1-8 \mathrm{X}_{1-8}$

\begin{tabular}{ccccccc}
\hline & Model & Sum of Squares & df & Mean Square & $F$ & Sig. \\
\hline 1 & Regression & 17.216 & 8 & 2.152 & $26.582^{\star}$ & $.000^{\mathrm{b}}$ \\
& Residual & 11.820 & 146 & .081 & & \\
& Total & 29.036 & 154 & & & \\
\hline
\end{tabular}

a. Dependent Variable: Ihsan Behavior

Table 6: Regression Coefficient of $\mathrm{Y}$ on $\mathrm{X}_{1-8}$

\begin{tabular}{|c|c|c|c|c|c|c|c|}
\hline \multirow{2}{*}{ Model } & \multicolumn{3}{|c|}{ Unstandardized Coefficients Standardized Coefficients } & \multicolumn{4}{|c|}{ Collinearity Statistics } \\
\hline & $\mathrm{B}$ & Std. Error & Beta & $\mathrm{t}$ & Sig. & Tolerance & VIF \\
\hline (Constant) & -648 & .314 & - & -2.062 & 2.041 & - & - \\
\hline Ambitious $\left(X_{1}\right)$ & .191 & .052 & .230 & 3.666 & .000 & .708 & 1.413 \\
\hline Certain $\left(X_{2}\right)$ & .011 & .068 & .010 & .155 & .877 & .625 & 1.601 \\
\hline Courageous $\left(X_{3}\right)$ & .051 & .067 & .045 & .755 & .452 & .781 & 1.280 \\
\hline Hard-working $\left(\mathrm{X}_{4}\right)$ & -.064 & .089 & -.051 & -.718 & .474 & .561 & 1.782 \\
\hline
\end{tabular}




\begin{tabular}{ccccccc}
\hline Ghirah $\left(\mathrm{X}_{5}\right)$ & .034 & .070 & .033 & .490 .625 & .603 & 1.659 \\
Patient \& Persistent $\left(\mathrm{X}_{6}\right)$ & .383 & .089 & .317 & 4.310 .000 & .516 & 1.937 \\
Generous $\left(\mathrm{X}_{7}\right)$ & .460 & .075 & .405 & 6.167 .000 & .645 & 1.551 \\
Grateful $\left(\mathrm{X}_{8}\right)$ & .069 & .063 & .064 & 1.090 .278 & .807 & 1.239 \\
\hline
\end{tabular}

a. Dependent Variable: Ihsan Behavior

Following the result of ANOVA in the above Table 5 and Table 6, the multiple linear regression model of the simultaneous correlation between ambitious $\left(X_{1}\right)$, certain/confident $\left(X_{2}\right)$, courageous $\left(X_{3}\right)$,

$$
Y=-0.648+0.191 X_{1}+0.011 X_{2}+0.051 X_{3}-0.064 X_{4}+0.034 X_{5}+0.383 X_{6}+0.460 X_{7}+0.069 X_{8}
$$

The significance test towards the multiple regression model $Y=-0.648+0.191 X_{1}+0.011 X_{2}+$ $0.051 X_{3}-0.064 X_{4}+0.034 X_{5}+0.383 X_{6}+0.460 X_{7}+$ $0.069 X_{8}$ shows a 'significant' result as the sig value $<$ $0.05(0.00<0.05)$ and the value of $F$ count $=26.583$ (see Table 5). Accordingly, the model mentioned previously is 'significant and applicable' to predict 'innovative behavior' by using $X_{1}-X_{8}$ data, if the data of those eight independent variables are identified.

The result of significance test on regression constant (a) and regression coefficient (b, c, d, e, f, g, $\mathrm{h}, \mathrm{i}$ ) is presented in Table 6 . The regression constant $a=-0.648$ is 'significant' as the sig value is $<0.05$ $(0.041<0.05)$. This indicates that the constant gives a significant effect on doing ihsan behavior. In addition, the regression coefficient of $\left(X_{1}\right)$ is $b=0.191 ; X_{6}$ is $g=$ 0.383 , and; $X_{7}$ is $h=0.460$. They get a 'significant' result in the regression coefficient significance test because the sig value $<0.05(0.00<0.05)$. Consequently, these three variables, i.e., ambitious $\left(X_{1}\right)$, patient \& persistent hard-working $\left(X_{4}\right)$, ghirah $\left(X_{5}\right)$, patient \& persistent $\left(X_{6}\right)$, generous $\left(X_{7}\right)$, and grateful $\left(X_{8}\right)$ and insan behavior $(Y)$ can be formulated, as follows:
$\left(X_{6}\right)$, and generous $\left(X_{7}\right)$ significantly influence the level of performing ihsan behavior. Meanwhile, the regression coefficient of $X_{2}$ is $c=0.011 ; X_{3}$ is $d=0.051$, and; $X_{4}$ is $e=-0.064, X_{5}$ is $f=0.034$, and $X_{8}$ is $i=0.069$. They get an insignificant result (see Table 6 ) in the regression coefficient significance test because the sig value $>$ $0.05(0.877,0.452,0.474,0.625$, and $0.278>0.05)$. Therefore, the variables of certain/confident $\left(X_{2}\right)$, courageous $\left(X_{3}\right)$, hard-working $\left(X_{4}\right)$, ghirah $\left(X_{5}\right)$, and grateful $\left(X_{8}\right)$ do not significantly affect_the level of insan behavior.

\section{b) The Best Regression Model (Good of Fit Model) to Predict Ihsan Behavior.}

The result of regression analysis of $Y$ (ihsan behavior) and eight independent variables, i.e., ambitious $\left(X_{1}\right)$, certain/confident $\left(X_{2}\right)$, courageous $\left(X_{3}\right)$, hard-working $\left(X_{4}\right)$, ghirah $\left(X_{5}\right)$, patient \& persistent $\left(X_{6}\right)$, generous $\left(X_{7}\right)$, and grateful $\left(X_{8}\right)$ and insan behavior $(Y)$ formulates the regression model, as follows:

$$
Y=-0.648+0.191 X_{1}+0.011 X_{2}+0.051 X_{3}-0.064 X_{4}+0.034 X_{5}+0.383 X_{6}+0.460 X_{7}+0.069 X_{8}
$$

It appears that five variables get insignificant regression coefficients (see Table 6), including certain/confident $\left(X_{2}\right)$, courageous $\left(X_{3}\right)$, hard-working $\left(X_{4}\right)$, ghirah $\left(X_{5}\right)$, and grateful $\left(X_{8}\right)$, in which the sig. value is greater than 0.05 . As a result, the model is "inadequate", meaning that an acceptable model (good of fit model) should be determined to predict Ihsan

behavior $(Y)$ by using three dependent variables with significant regression coefficients (sig. value $<0.05$ ) as predictors. Those are ambitious $\left(X_{1}\right)$, patient \& persistent $\left(X_{2}\right)$, and generous $\left(X_{3}\right)$. Provided in the table below is the result of correlation and regression analysis for 'good of fit model' to shape 'ihsan qualities'.

Table 7: Multiple Correlation of $Y \& X_{1}, X_{2}$ and $X_{3}$

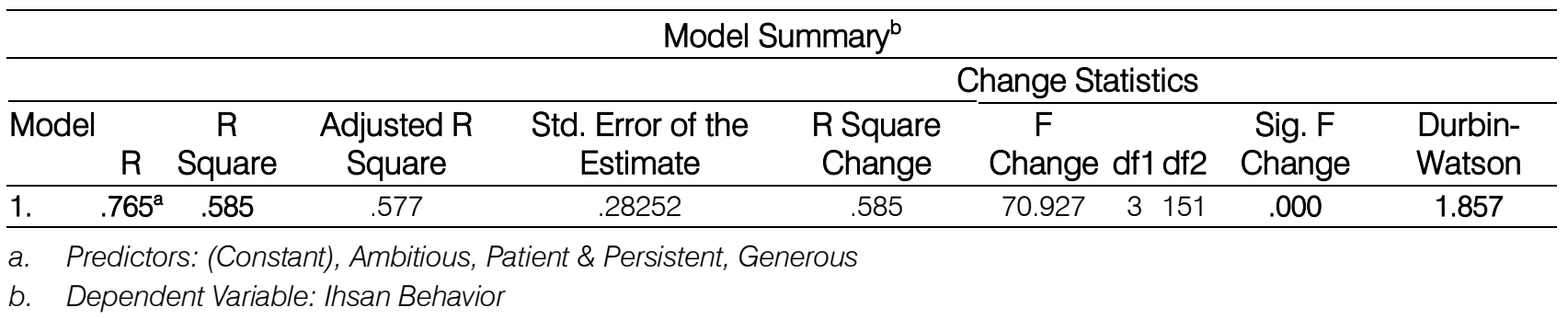

The multiple correlation analysis of the simultaneous correlation between ambitious $\left(X_{1}\right)$, patient \& persistent $\left(X_{2}\right)$, and generous $\left(X_{3}\right)$ and ihsan behavior $(Y)$ results in multiple correlation coefficient $R=0.765$; such a correlation is 'positive and strong'. Next, the determination coefficient $\left(R^{2}\right)$ gets a value of 0.585 , implying that variables of ambitious $\left(X_{1}\right)$, patient \& persistent $\left(X_{2}\right)$, and generous $\left(X_{3}\right)$ simultaneously 
contribute to insan behavior $(Y)$ by $58.5 \%$; the remaining $41.5 \%$ is contributed by other factors. The analysis result of the regression of $Y$ on $X_{1}, X_{2}$ and $X_{3}$ is illustrated in the following Table 8 and Table 9.

Table 8: ANOVA of $\mathrm{Y}$ on $\mathrm{X}_{1}, \mathrm{X}_{2}$, and $\mathrm{X}_{3}$

\begin{tabular}{ccccccc}
\hline \multicolumn{8}{c}{ ANOVA $^{\mathrm{a}}$} & & & \\
\hline & Model & $\begin{array}{c}\text { Sum of } \\
\text { Squares }\end{array}$ & df & Mean Square & F & Sig. \\
\hline \multirow{2}{*}{1} & Regression & 16.983 & 3 & 5.661 & 70.927 & $.000^{\mathrm{b}}$ \\
& Residual & 12.052 & 151 & .080 & & \\
& Total & 29.036 & 154 & & & \\
\hline
\end{tabular}

a. Dependent Variable: Ihsan Behavior

b. Predictors: (Constant), Ambitious, Patient \& Persistent, Generous

Table 9: Regression Coefficient of $Y$ on $X_{1}, X_{2}$ and $X_{3}$

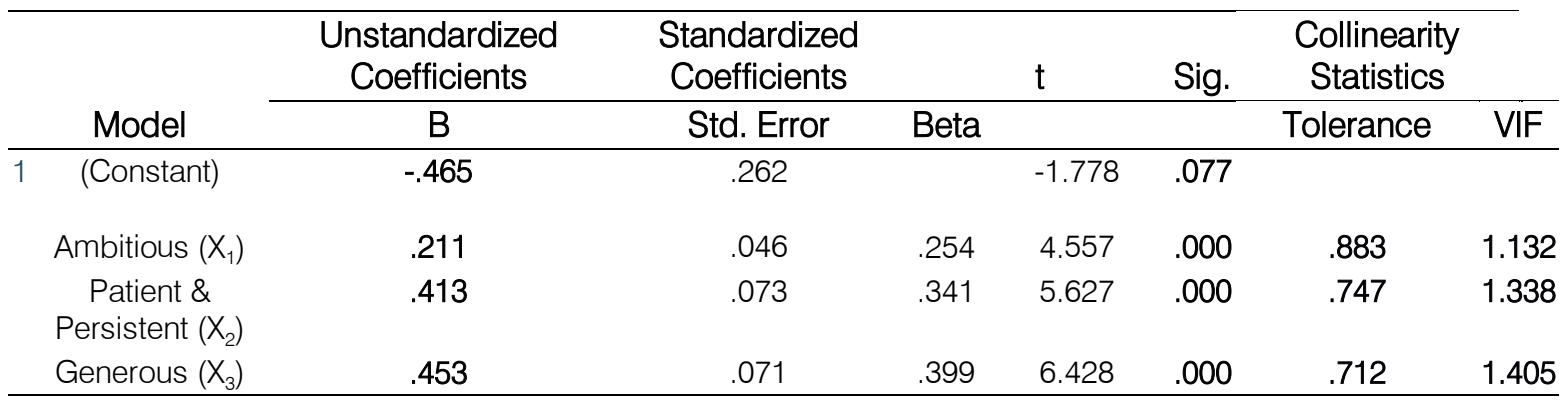

Based on the result of ANOVA, as shown in the above tables, a multiple linear regression model of the simultaneous correlation between ambitious $\left(X_{1}\right)$, patient \& persistent $\left(X_{2}\right)$, and generous $\left(X_{3}\right)$ and ihsan behavior can be formulated as the Good of Fit Model, as follows:

$$
Y=-0.465+0.211 X_{1}+0.413 X_{2}+0.453 X_{3}
$$

The significance test towards the multiple regression model $Y=-0.465+0.211 X_{1}+0.413 X_{2}+$ $0.453 X_{3}$ shows a 'significant' result as the sig. value $<0.05(0.00<0.05)$ and the value of $F$ count $=70.927$ (see Table 8). Accordingly, the model mentioned previously is 'significant and exigent' to predict 'innovative behavior' by using $X_{1}, X_{2}$, and $X_{3}$ data, if the data of those three independent variables are known.

The result of significance test on regression constant (a) and regression coefficient presented in Table 9 is $a=-0.465$ and 'significant' as the sig. value is $<0.05(0.00<0.05)$. Thus, the constant has a significant effect on doing ihsan behavior. In addition, the regression coefficient of $X_{1}$ is $b=0.211 ; X_{2}$ is $c=0.413$, and; $X_{3}$ is $d=0.433$. They get a 'significant' result in the regression coefficient significance test because the sig. value $<0.05(0.00<0.05)$. As a consequence, these three variables, i.e., ambitious $\left(X_{1}\right)$, patient \& persistent $\left(X_{2}\right)$, and generous $\left(X_{3}\right)$, significantly influence the level of performing insan behavior. They feature a level of sensitivity of the great effect on ihsan behavior, in which the highest sensitivity achieved by generous $=0.453$, and followed by both patient \& persistent $=0.413$ and ambitious $=0.211$.

\section{Discussion}

The instruction of doing ihsân is clearly written in QS. An-Nisa [4:36], as follows: "Worship Allah and associate nothing with Him. And do goods to parents, relatives, orphans, the needy, the near neighbors, the distant neighbors, the companion at your side, the travelers, and those whom your right hands possess. Indeed, Allah does not like the self-deluding and the boastful". (QS. An-Nisa/4: 36). The behavior of ihsân, as mentioned in the verse, is the second-highest virtue in Islam after the belief in Allah (tawhid) as the first. Those who can do good to others (ihsân) are called muhsin/mushinîn. In the Qur'an, no less than 15 times, Allah SWT relies His love on people who do and behave insan, as in this verse: "...And those who restrain anger and forgive people [mistake]. Allah loves the doers of good." (QS. Ali 'Imran/3: 134). According to Hazii (2020) that the implementation of Ihsan's behavior in an institution/organization/company in general for three, namely: a) Organization Ihsan Behavior-Employee toward Employee (ihsan behavior between colleagues/ employee to employee); b) Organization Ihsan BehaviorEmployee toward Organization (Ihsan behavior between employee to supervisor/head of work unit) and c) Organization Ihsan Behavior-Organization toward Employee (ihsan behavior between the organization leadership to the employee), and if applying the three 
ihsan behavior in the activities of the institution/ organization/company is ensured can produce optimal performance. As Wahab \& Ismail research (2019:187) that ihsan behavior containing key work values allows an institution/organization/company to produce high employee performance.

In the Qur'an, faith and righteous deeds are always mentioned together; they are inextricably linked with each other. Generosity is an essential part of righteous deeds that should be shown as evidence of faith. The Prophet Muhammad, in a hadith, explains that Muslims should care about each other, as narrated in Shahih Imam Thabrani which means: 'Whosoever of you do not care about the Muslims is not one of them. (Shahih Imam Thabrani Number 74730.) Further-more according to Collett \& Morrissey (2007: 21) generosity is a character in which a person voluntarily gives his or her time, talents and possessions to help others, and is a mandatory and voluntary behavior oriented towards providing welfare to others. Generosity is a manifestation of the love of Allah and Prophet Muhammad. As widely acknowledged, Allah SWT is The Most Gracious, The Most Merciful. Further, the Prophet Muhammad is compassionate and merciful. Muslims are asked to continue the love of Allah and the Prophet Muhammad to human beings by doing good deeds (ihsân) and being generous. Narrated in a hadith, Allah SWT will help a person who also helps his brother. The Prophet Muhammad said: 'Allah is always helping the servant as long as the servant is helping his brother' [Shahih Muslim, Thurmudy, Abud Daud, Ibn Majah, and Ahmad]; Imam al-Albani viewed this hadith to be authentic.

The second dominant quality that contributes to insan behavior is patient \& persistent in striving for and helping others. Ihsân behavior requires patience and persistence as one should resist indolence, miserliness, and selfishness to behave well. Patience, in this case, refers to being patient to accept difficulties, to fulfill obligations, i.e., helping other individuals, and to resist worldly desires and selfishness. Persistence is also important on account of the necessity of making a considerable effort to perform good deeds (ihsân). One with no patience and persistence in patience is not able to develop ihsân behavior as the highest religious behavior. Allah says in QS. Ali 'Imran [3:200]: "Believers, endure and be more patient and hold yourselves ready (on the border of your territory) and be pious to Allah that you may find success" (QS. Ali 'Imran/3: 200). Patience, as mentioned in the aforementioned verse, is required to gain the highest religious degree, and success. Ihsân behavior should be striven for the whole life, meaning that developing insân behavior takes a great deal of effort and time. For such reasons, patience and persistence are determinant factors of shaping insân behavior. Further-more according to Subandi (2011:220) it is mentioned that there are two kinds of ways to train patience, namely: a) realize that everything in this world is not eternal and changes all the time, what is unpleasant is not always disturbing; b) think that everything that happens to a person is the result of his own actions.

The third dominant quality determining ihsan behavior is ambitious in views of the vision of people's betterment and prosperity. According to Barsukova (2016: 80) in general the goal of a person has ambition is to gain recognition of what he wants from others his social environment as well as his professional community. In this case in Islam and Muslims betterment has become the fundamental and supporting aspect of ihsân behavior development. Unambitious or narrow-minded people will be more likely to work and do something for their own improvement. Simply put, without understanding the vision mentioned previously, it takes a lot of energy to urge someone to behave ihsân. The behavior of ihsân is interpreted as a willingness to share with and help other people towards the best Islamic community (ummah), as Allah says in QS. Ali 'Imran [3:110]: "You are the best people raised up for mankind, enjoining what is right, forbidding what is wrong, and believing in Allah. If only the People of the Book had faith, it would indeed have been better for them, some of them are believers, but most are transgressors". (QS. Ali 'Imran/3: 110). The above verse depicts a big vision of becoming the best community (ummah), i.e., human beings that can perform three acts of goodness as the component of insân, as follows: a) humanization: a matter of promoting human dignity; b) liberation: setting people free from the spiritual disease of the heart; 3) spiritualization: encouraging humans to acknowledge and believe in Allah to enlighten the heart and mind.

Being generous, patient \& persistent, and ambitious are three dominant qualities that influence insan behavior. Other qualities include certain/confident, courageous, hard-working, ghirah, and grateful. All these qualities simultaneously and positively contribute to shaping insan behavior by $60 \%$; the remaining $40 \%$ is influenced by other factors, such as education, experience, family, school, and society. An individual educated and raised in a family, school, and community environment that has a decent Islamic background will tend to have a strong insân behavior. On top of that, insân behavior is also affected by values and cultures prevailing in societal life. People with high cooperative, collective, and collegial values will have the chance to grow and develop the behavior of insân (always do the good deeds).

\section{Conclusions}

a. There is a simultaneous and strong correlation between ambitious, certain/confident, courageous, hard-working, ghirah, patient \& persistent, generous, and grateful and ihsan behavior with the 
multiple correlation coefficient of 0.770 . On that ground, the higher the score of the eight qualities, the greater one's opportunity to behave ihsan.

b. All variables of ambitious, certain/confident, courageous, hard-working, ghirah, patient \& persistent, generous, and grateful simultaneously get the determination coefficient $\left(R^{2}\right)$ of 0.60 . Thus, these qualities contribute to shaping ihsan behavior by $60 \%$; the other $40 \%$ is contributed by other factors.

c. Mathematical equation model: $Y=-0.648+0.191$ $X_{1}+0.011 X_{2}+0.051 X_{3}-0.064 X_{4}+0.034 X_{5}+$ $0.383 X_{6}+0.460 X_{7}+0.069 X_{8}$. The model is 'significant and applicable' to predict 'innovative behavior' by using $X_{1}-X_{8}$ data simultaneously, if the data of those eight independent variables are identified.

d. By taking into account the regression coefficient, only ambitious $\left(X_{1}\right)$, patient \& persistent $\left(X_{6}\right)$, and generous $\left(X_{7}\right)$ in the model of $Y=-0.648+0.191 X_{1}$ $+0.011 X_{2}+0.051 X_{3}-0.064 X_{4}+0.034 X_{5}+0.383$ $\mathrm{X}_{6}+0.460 \mathrm{X}_{7}+0.069 \mathrm{X}_{8}$ that significantly and dominantly influence the development of ihsan behavior. In contrast, the other five qualities: certain $\left(X_{2}\right)$, courageous $\left(X_{3}\right)$, hard-working $\left(X_{4}\right)$, ghirah $\left(X_{5}\right)$, and grateful $\left(X_{8}\right)$ do not have a significant effect. Finally, the best model (good of fit model) to predict 'ihsan behavior' uses ambitious, patient \& persistent, and generous as variables with a significant or dominant effect.

e. Ambitious, patient \& persistent, generous and ihsan behavior (doing good deeds) have a 'positive and strong' correlation with a correlation coefficient of 0.765 . This implies that the higher the score of ambitious, patient \& patient, and generous qualities, the greater one's opportunity to behave ihsan;

f. Three qualities of ambitious, patient \& persistent, generous simultaneously show a determination coefficient $\left(R^{2}\right)$ of 0.585 , indicating that they contribute to shaping ihsan behavior by $58.5 \%$; the remaining $41.5 \%$ is contributed by other factors, namely education, experience, environment, community culture, social capital, and the rest.

g. The best mathematical model (Good of Fit Model) to predict the level of insan behavior by using the variables of ambitious, patient \& persistent, and generous is $Y=-0.465+0.211 X_{1}+0.413 X_{2}+$ $0.453 X_{3}$. The negative sign in the constant: -0.465 brings out the fact that the absence of ambitious $\left(X_{1}\right.$ $=0)$, patient \& persistent $\left(X_{2}=0\right)$, and generous $\left(X_{3}\right.$ $=0)$ qualities will lead to negative or decreasing ihsan behavior (- 0.465).

h. The sequence of the sensitivity level of the effect of ambitious, patient \& persistent, and generous qualities on shaping ihsan behavior (always do the good deeds ) is given below.
- First: Generous (0.453)

- Second: Patient \& Persistent (0.413)

- Third: Ambitious (0.211)

Note:

Funding: This research received no external funding Conflicts of Interest: The author declares no conflict of interest

Availability data: Data of research is transparency

Code software: IBM SPSS Statistics 24- 2016, X86-X64, DSI 2983

\section{References Références Referencias}

1. Akmal \& Masyhuri. (2018). Konsep Syukur [The Concept of Gratefulness]. Jurnal Komunikasi dan Pendidikan Islam 7(2), 1-22.

2. Alias, M. S. (2017). Tingkat-Tingkat Keyakinan IImu Dalam Islam:Suatu Penelitian Aksiologi [Levels of Belief in Islamic Sciences: An Axiology Study]. Ulwan's Journal 1, 1-18.

3. Alma B. (2010). Learning Social Studies. Alfabeta.

4. United Nations. (2010). United Nations Competency Development: A Practical Guide, Human Resources Management. United Nations.

5. Alwi, M., A., Sylvana, A., Risnashari. (2016). Pengaruh Semangat Kerja Pegawai Terhadap Keefektifan Organisasi Unit Program BelajarJarak Jauh Universitas Terbuka Makassar [The Influence of Employee Morale Towards the Effectiveness of the Organization of the Makassar Open University Long Distance Learning Program]. Jurnal Analisis Kebijakan \& Pelayanan Publik 2(1), 31-45.

6. Anderson, L. W. \& Krathwohl, D. R. (Ed). (2001). A Taxonomy for Learning, Teaching and Assessing, A Revision of Bloom's Taxonomy of Educational Objectives. Longman Inc.

7. Bakar, Osman, (1994). Tauhid and Science: Essays on History and Philosophy of Islamic Sciences. Pustaka Hidayah.

8. Barsukova O.V. (2016). Psychological Characteristics of Ambitious Person. Journal of Process Management- New Technologies International, 4(2), 79-80. DOI: 10.5937/JPMNT 60 2079B.

9. Collett, J. L. \& Morrissey C. A. (2007). The Social Psychology of Generosity: The State of Current Interdisciplinary Research, South Bend: Department of Sociology, University of Notre Dame.

10. Ernadewita \& Rosdialena. (2019). Sabar Sebagai Terapi Kesehatan Mental [Patience as a Mental Health Therapy]. Jurnal Kajian Dan Pengembangan Umat, 3(1), 45-65.

11. Handayani, W. \& Sumaryati. (2014). Upaya Orang Tua dalam Menanamkan Karakter Kerja Keras Anak Usia Remaja di Dusun Tegalyoso Banyuraden 
Gamping Sleman Yogyakarta [The Effort to Instill the Hard Work of Young Children in the Village of Tegalyoso Banyuraden Gamping Sleman Yogyakarta]. Journal Citizenship Journal, 4(1), 27-38. DOI: http://dx.doi.org/10.12928/citizenship.v4i1. 6280.

12. Haryanto H.C., Kertamuda, F.E. (2016). Syukur Sebagai Sebuah Pemaknaan [Gratitude as a Meaningful]. InSight Journal IImiah Psikologi, 18(2), 109-118.

13. Hazzi, O. (2020). Organizational Ihsan Behavior, Farazmand, A. (Ed). Springer Link. doi: https://doi. org/10.1007/978-3-319-31816-5 4039-1.

14. Hill N. (2013). New Think and Grow Rich, Translation by Lulu Fitri Rahman dan Leinovar Bahfein. Ufuk Press.

15. Ihwanto, M. A., Anwar Sutoyo, A. \& Sudarmin. (2017). Desain Pendidikan Karakter Berbasis NilaiNilai Insan bagi Siswa MI NU Salafiyah Kudus [Design of character education based on the values of Ihsan for MI-NU Salafiyah Kudus Students]. Innovative Journal of Curriculum and Educational Technology (IJCET), 6(1), 1-10.

16. Ismail, A, I. (2018). The True Winner in An Islamic Perspective. Mitra Wacana Media.

17. King, A. L. (2010). Psikologi Umum [General Psychology]. Salemba Humanika.

18. Subandi. (2011). Sabar: Sebuah Konsep Psikologi [Patience: A Concept of Psychology]. Psychology Journal, 38(2), $215-227$.

19. Subiantoro, D. A., Utari, W., Hartati, S. (2019). Working Spirit Analysis, Working Environment and Working Motivation Against the Work of Regional Secretariat Officers of Bojonegoro Regency. Journal Mitra Management Journal, 3(4), 424-437.

20. Susanto A.N. (2015). How to Build Business Blessings. PT. Vindra Sushantco Putra.

21. Stoltz, P. G. (1997). Adversity Quotient. John Wiley \& Sons, Inc.

22. Tabi'in, A. (2017). Foster Child Care Attitude through Social Activity Interaction. Ijtimaiya Journal of Social Science Teaching, 1(1), 40-59.

23. Hidayati, T., U, Alfiandra, Waluyati, S. H. (2019). Pengaruh Kecerdasan Emosional Terhada Sikap Peduli Sosial Siswa Di SMP Negeri 1 Palembang [The Effect of Emotional Intelligence on Students ' Social Care Attitude at SMP Negeri 1 Palembang]. Bhineka Tunggkal Ika Journal, 6(1), 17-36. DOI: 10.36706/jbti.v6i1.7920.

24. Wahab M. A. \& Ismail Y. (2019). Mas'uliyyah and Ihsan as High-Performance work values in Islam. International Journal of Economics, Management and Accounting, 27(1), 187-212.

25. Yulk, Gary. (2013). Leadership in Organizations, Eighth Edition. Pearson Education Limited. 